\title{
EFFICIENCY OF MILKING COWS USING ROBOT IN A LARGE HERD
}

Stanisław Winnicki ${ }^{a}$, Wacław Romaniuk ${ }^{\mathrm{a}}$, Paulina Mielcarek-Bocheńska ${ }^{\mathrm{a}^{*}}$, Andrzej Borusiewicz ${ }^{\mathrm{b}}$, Jan Barwicki ${ }^{\mathrm{a}}$

${ }^{a}$ Institute of Technology and Life Sciences, Falenty/n. Warsaw, Poland, e-mail: s.winnicki@itp.edu.pl, ORCID 0000-0003-1547-3583; w.romaniuk@itp.edu.pl, ORCID 0000-0001-7776-9940; p.mielcarek@itp.edu.pl, ORCID 0000-0003-0538-013X; jbarwicki@gmail.com, ORCID 0000-0002-5437-5284

b Higher School of Agribusiness in Lomza, Poland, e-mail: andrzej.borusiewicz@wsa.edu.pl, ORCID 0000-0002-1407-7530

*Corresponding author: email: p.mielcarek@itp.edu.pl

\begin{tabular}{|c|c|}
\hline ARTICLE INFO & ABSTRACT \\
\hline $\begin{array}{l}\text { Article history: } \\
\text { Received: September } 2019 \\
\text { Received in the revised form: } \\
\text { November } 2019 \\
\text { Accepted: December } 2019 \\
\end{array}$ & $\begin{array}{l}\text { The aim of the study was to carry out a research on the use of milking } \\
\text { robots compared to utilization of milking parlors. There was no such } \\
\text { study in literature on the milking farms in Poland and abroad. The pre- } \\
\text { sented study, except for scientific knowledge, provides also practical } \\
\text { utilization as a good agriculture practice on the farm. Tests were carried }\end{array}$ \\
\hline $\begin{array}{l}\text { Key words: } \\
\text { cow; } \\
\text { milking robot; } \\
\text { milk; } \\
\text { chemical quality; } \\
\text { cytological quality; } \\
\text { uniformity of production }\end{array}$ & $\begin{array}{l}\text { out simultaneously in two barns belonging to the same farm. In barn K, } \\
\text { milking was used in the rib bone milking parlor, and in barn N with } \\
\text { milking robots. The results covering three years of research from } 2016 \\
\text { to } 2018 \text { were presented. It was concluded that the milk yield of young } \\
\text { cows in both barns was almost identical, while in the second and sub- } \\
\text { sequent lactation, cows in barn N had higher yield. In barn N, about } 3 \% \\
\text { more milk was obtained from LKS below } 400 \text { thaus. } \mathrm{ml}^{-1} \text {, compared to } \\
\text { barn } \mathrm{K} \text {. Time of cows' utilization in both cowsheds was similar, while } \\
\text { in barn N the life efficiency of culled cows was higher by about } 1,000 \\
\text { kg of milk. The level of deficiency and its structure, due to the number } \\
\text { and stage of lactation, were very similar in both barns. In barn N, the } \\
\text { uniformity of milk production throughout the year was more even com- } \\
\text { pared to barn K. There were reserves in the use of the milking robot due } \\
\text { to the low number of cows per milking stand and the need to better } \\
\text { adaptation of milking times to current cow performance. The milking } \\
\text { robot improves cow welfare and ensures high milk yield and good cy- } \\
\text { tological quality of milk. }\end{array}$ \\
\hline
\end{tabular}

\section{Introduction}

Poland is a significant, large milk producer. Currently, the annual milk production in Poland amounts to ca. 13.5 billion liters per year, and purchase by milk processing plants is around 11.6 billion liters (Szajner, 2017). This gives the fifth place in Europe and the sixth in the world in terms of the production volume. Exports of dairy products account for around $35 \%$ of the purchased milk and account for $26 \%$ of the dairy's revenues. In recent years there have been major quantitative and qualitative changes in both milk production and processing. 
Even in the 90s of the twentieth century, the breeding of cows was very fragmented, because it was carried out in about 1.5 million farms. Before joining the EU, 98.2\% of farms had a tied-up cow farming system (Barańska et al., 2003). Currently, around 110,000 farmers are involved in milk production and more often cows are kept in a free stall system and they are milked in the milking parlor.

Until recently, the most labor-intensive and burdensome work in the barn was milking. However, it improved dramatically when milking robots were constructed. The first milking robot in the world was developed by Lely, which began milking in a farm in the Netherlands in 1992. Currently, all leading milking companies produce robots (Lehnert, 2012).

In Poland, the first robots were launched in 2008 by DeLaval, while the Lely robots in 2010. Currently, several hundred milking robots, mainly these by two companies, are in use in Poland. The introduction of milking robots radically changed the input and nature of work in the barn (Winnicki and Jugowar, 2018). There are no studies in the literature comparing the robot milking or in the milking parlor, based on national tests.

The aim of the study was to compare the level of milk production and its chemical and cytological quality in herds using robot and milking parlor.

\section{Materials and Methods}

The study was carried out simultaneously in two barns belonging to the same state-owned farm. The study lasted three years - from 2016 to 2018. In both herds there were cows of the Polish Holstein-Friesian breed of black and white (PHF-HO). The herd was renovated from a joint heifer rearing school. The same production technology was used in both barns (Table 1).

Table 1.

Basic characteristics of technology in the investigated barns

\begin{tabular}{|c|c|c|}
\hline \multirow{2}{*}{ Element } & \multicolumn{2}{|c|}{ The solution used in the barn } \\
\hline & $\mathrm{K}$ & $\mathrm{N}$ \\
\hline \multirow[b]{2}{*}{ Housing system } & \multicolumn{2}{|c|}{$\begin{array}{l}\text { free stall barn, } \\
\text { with litter stalls and full floor in the corridors }\end{array}$} \\
\hline & $\begin{array}{l}\text { in technological and nutritional } \\
\text { groups } \\
\text { of young cows in a separate group }\end{array}$ & $\begin{array}{c}\text { random group assignment, group size } \\
\text { depending on the number of milking } \\
\text { robots }\end{array}$ \\
\hline Milking & $\begin{array}{c}\text { A herringbone milking parlor } \\
2 \times 8 \text { stands of Westfalia Company } \\
\text { (GEA) }\end{array}$ & $\begin{array}{c}2 \times 2+2 \times 1+1=7 \text { Astronaut A4 milking } \\
\text { robots of Lely Company, } \\
\text { free access to milking }\end{array}$ \\
\hline Feeding & TMR in 5 nutritional groups & $\begin{array}{c}\text { The same PMR for the whole herd, } \\
\text { feeding with concentrated feed during } \\
\text { milking }\end{array}$ \\
\hline Manure removal & $\begin{array}{l}\text { Front-end loader - } \\
\text { once a day }\end{array}$ & $\begin{array}{l}\text {,delta" scraper } \\
-6 \text { times a day }\end{array}$ \\
\hline
\end{tabular}

The difference between concerned herds milking systems; cows in a conventional barn (K) were milked in a milking parlor, and in a modern barn $(\mathrm{N})$ were using milking robots. 
Efficiency of milking cows...

The output figures came from two sources:

- from dairy control of cows conducted by the AR4 method for three years 2016-2018; the resulting reports RW1 and RW2 were used,

- from the Lely herd's IT system: FMS Farm Scan and Milking - behavior during the milking visit and herd review.

The data were analyzed for a total of 958 lactations, each lasting 305 days. General data on the number of the analyzed lactations broken down into lactation numbers and cowshed number are presented in Table 2.

Table 2.

Distribution of lactation by number in barn $\mathrm{K}$ and $\mathrm{N}$.

\begin{tabular}{lccc}
\hline \multirow{2}{*}{ Lactation number } & \multicolumn{3}{c}{ Number of lactations in the herd } \\
\cline { 2 - 4 } & $\mathrm{K}$ & $\mathrm{N}$ & Total \\
\hline 1 & 120 & 230 & 350 \\
2 & 65 & 216 & 281 \\
3 & 29 & 136 & 165 \\
$\geq 4$ & 33 & 129 & 162 \\
Total & 247 & 711 & 958 \\
\hline
\end{tabular}

Table 3.

Number of milk tests on somatic cells (LKS) in herds $K$ and $N$ in 2016-2018

\begin{tabular}{lccc}
\hline \multirow{2}{*}{ Year } & \multicolumn{3}{c}{ Total number of milk samples in the barn } \\
\cline { 2 - 4 } & $\mathrm{K}$ & $\mathrm{N}$ & Total \\
\hline 2016 & 1,994 & 3,392 & 5,386 \\
2017 & 1,818 & 3,802 & 5,620 \\
2018 & 1,897 & 3,562 & 5,459 \\
Total & 5,709 & 10,756 & 16,465 \\
\hline
\end{tabular}

The results were subjected to calculations of descriptive statistics, and the significance of differences between objects were developed using the Mann-Whitney U test.

\section{Results and Discussion}

When comparing the impact of various factors affecting the productivity of dairy cows, in order to characterize it, the values of indicators such as the level of milk production and its chemical composition, mainly fat, protein and dry matter are commonly used. The most general indicator is the average annual herd performance. More specific are the performance for

\section{yield}

Table 4 shows the average annual milk yields. In both herds, high yields were achieved, higher than the average yields of the PHF-HO cows, which in Poznan region in 2018 amounted to $9,171 \mathrm{~kg}$. The data in Table 4 indicate that for all three analyzed years, the herd kept in a modern $\mathrm{N}$ barn had greater efficiency than the herd in a conventional $\mathrm{K}$ barn. 
S. Winnicki, W. Romaniuk, P. Mielcarek-Bocheńska, A. Borusiewicz, J. Barwicki

Table 4.

Average annual milk yield in the analyzed herds in 2016-2018

\begin{tabular}{|c|c|c|c|c|c|c|c|c|}
\hline \multirow{2}{*}{ Barn } & \multirow{2}{*}{ Year } & \multirow{2}{*}{$\begin{array}{l}\text { Number } \\
\text { of cows }\end{array}$} & \multicolumn{3}{|c|}{ Mean yield $(\mathrm{kg})$} & \multicolumn{2}{|c|}{ Mean content $(\%)$} & \multirow{2}{*}{$\begin{array}{c}\text { Calving } \\
\text { interval (days) }\end{array}$} \\
\hline & & & milk & fat & protein & fat & protein & \\
\hline \multirow{3}{*}{ K } & 2016 & 208.9 & 9,294 & 341 & 319 & 3.67 & 3.43 & 416 \\
\hline & 2017 & 216.4 & 9,478 & 365 & 323 & 3.85 & 3.41 & 391 \\
\hline & 2018 & 232.6 & 10,275 & 402 & 349 & 3.91 & 3.39 & 394 \\
\hline \multirow{3}{*}{$\mathrm{N}$} & 2016 & 362.9 & 10,611 & 412 & 359 & 3.88 & 3.38 & 397 \\
\hline & 2017 & 406.8 & 10,895 & 411 & 363 & 3.77 & 3.33 & 387 \\
\hline & 2018 & 384.2 & 12,108 & 458 & 400 & 3.78 & 3.30 & 383 \\
\hline Greater Poland & 2018 & 186,300 & 9,171 & 359 & 310 & 3.91 & 3.38 & 426 \\
\hline
\end{tabular}

\section{Performance for standard lactation}

Milk yield changes in subsequent lactations. Usually it is the highest in the third lactation, and from the fourth lactation it gradually decreases. In the herds studied, the milk yield in the element was over 9.6 thousand. $\mathrm{kg}$ and was by $1,300 \mathrm{~kg}$ higher compared to the average in Greater Poland (Poznan region) - Table 5. The difference exceeded $4 \mathrm{~kg}$ per day.

Table 5.

Average cow yield for 305 lactation days depending on lactation number

\begin{tabular}{|c|c|c|c|c|c|c|c|c|c|}
\hline \multirow[b]{2}{*}{ Lactation } & \multirow[b]{2}{*}{ Barn } & \multirow{2}{*}{$\begin{array}{l}\text { Statistical } \\
\text { parameter }\end{array}$} & \multicolumn{4}{|c|}{ Yield (kg) } & \multicolumn{3}{|c|}{ Content $(\%)$} \\
\hline & & & milk & fat & protein & $\begin{array}{c}\text { dry } \\
\text { matter }\end{array}$ & fat & protein & $\begin{array}{c}\text { dry } \\
\text { matter }\end{array}$ \\
\hline \multirow{7}{*}{1} & \multirow{3}{*}{$\mathrm{K}$} & mean & 9,611 & 366.1 & 327.4 & $1,256.0$ & 3.87 & 3.44 & 13.1 \\
\hline & & $\mathrm{SD}^{1}$ & 1,876 & 67.4 & 57.6 & 217.8 & 0.60 & 0.21 & 0.71 \\
\hline & & $\mathrm{CV}^{2}$ & 19.5 & 18.4 & 17.6 & 17.3 & 15.4 & 6.0 & 5.4 \\
\hline & \multirow{3}{*}{$\mathrm{N}$} & mean & 9,687 & 357.0 & 320.0 & $1,222.0$ & 3.72 & 3.32 & 12.7 \\
\hline & & $\mathrm{SD}$ & 1,433 & 47.1 & 42.6 & 158.5 & 0.38 & 0.19 & 0.54 \\
\hline & & $\mathrm{CV}$ & 14.8 & 13.2 & 13.3 & 12.9 & 10.2 & 5.7 & 4.3 \\
\hline & $\begin{array}{l}\text { Greater } \\
\text { Poland }\end{array}$ & mean & 8,304 & 320 & 276 & - & 3.85 & 3.32 & - \\
\hline \multirow{7}{*}{2} & \multirow{3}{*}{ K } & mean & 11,240 & 419.6 & 377.0 & $1,436.2$ & 3.76 & 3.36 & 12.82 \\
\hline & & SD & 1,923 & 92.7 & 64.3 & 249.6 & 0.62 & 0.19 & 0.76 \\
\hline & & $\mathrm{CV}$ & 17.1 & 22.1 & 17.1 & 17.4 & 16.6 & 5.5 & 5.9 \\
\hline & \multirow{3}{*}{$\mathrm{N}$} & mean & 11660 & 431.0 & 385.8 & $1,465.4$ & 3.72 & 3.32 & 12.60 \\
\hline & & SD & 1,668 & 58.5 & 52.6 & 189.3 & 0.40 & 0.19 & 0.54 \\
\hline & & $\mathrm{CV}$ & 14.3 & 13.6 & 13.6 & 12.9 & 10.7 & 5.6 & 4.3 \\
\hline & $\begin{array}{l}\text { Greater } \\
\text { Poland }\end{array}$ & mean & 9,095 & 352 & 305 & - & 3.87 & 3.35 & - \\
\hline \multirow{7}{*}{3} & \multirow{3}{*}{$\mathrm{K}$} & mean & 11,021 & 432.4 & 365.1 & $1,422.3$ & 4.00 & 3.36 & 13.00 \\
\hline & & $\mathrm{SD}$ & 2,897 & 115.4 & 87.9 & 353.0 & 0.69 & 0.24 & 0.88 \\
\hline & & $\mathrm{CV}$ & 26.3 & 26.7 & 24.1 & 24.8 & 17.3 & 7.2 & 6.7 \\
\hline & \multirow{3}{*}{$\mathrm{N}$} & mean & 11,611 & 438.9 & 381.7 & $1,462.8$ & 3.80 & 3.30 & 12.63 \\
\hline & & SD & 1,740 & 62.8 & 52.9 & 203.6 & 0.35 & 0.19 & 0.52 \\
\hline & & $\mathrm{CV}$ & 15.0 & 14.3 & 13.9 & 13.9 & 9.3 & 5.8 & 4.1 \\
\hline & $\begin{array}{l}\text { Greater } \\
\text { Poland }\end{array}$ & mean & 9,308 & 365 & 308 & - & 3.92 & 3.31 & - \\
\hline
\end{tabular}

90 
Efficiency of milking cows...

\begin{tabular}{|c|c|c|c|c|c|c|c|c|c|}
\hline \multirow[b]{2}{*}{ Lactation } & \multirow[b]{2}{*}{ Barn } & \multirow{2}{*}{$\begin{array}{l}\text { Statistical } \\
\text { parameter }\end{array}$} & \multicolumn{4}{|c|}{ Yield (kg) } & \multicolumn{3}{|c|}{ Content $(\%)$} \\
\hline & & & milk & fat & protein & $\begin{array}{c}\text { dry } \\
\text { matter }\end{array}$ & fat & protein & $\begin{array}{c}\text { dry } \\
\text { matter }\end{array}$ \\
\hline \multirow{7}{*}{$\geq 4$} & \multirow{3}{*}{$\mathrm{K}$} & mean & 9,811 & 376.7 & 344.0 & $1,252.0$ & 3.91 & 3.43 & 12.84 \\
\hline & & $\mathrm{SD}$ & 2,405 & 87.2 & 73.4 & 283.2 & 0.67 & 0.21 & 0.77 \\
\hline & & $\mathrm{CV}$ & 24.5 & 23.1 & 22.0 & 22.6 & 17.0 & 6.2 & 6.0 \\
\hline & \multirow{3}{*}{$\mathrm{N}$} & mean & 11,532 & 440.2 & 380.4 & 1,454 & 3.85 & 3.32 & 12.65 \\
\hline & & $\mathrm{SD}$ & 1,758 & 56.8 & 48.9 & 191.0 & 0.41 & 0.23 & 0.59 \\
\hline & & $\mathrm{CV}$ & 15.2 & 12.9 & 12.8 & 13.1 & 10.7 & 6.9 & 4.6 \\
\hline & $\begin{array}{l}\text { Greater } \\
\text { Poland }\end{array}$ & mean & 8,850 & 351 & 291 & - & 3.97 & 3.29 & - \\
\hline
\end{tabular}

${ }^{1} \mathrm{SD}$ - standard deviation; ${ }^{2} \mathrm{CV}$ - coefficient of variation.

In both herds in the second and third lactation, the average yield exceeded 11 thousand $\mathrm{kg}$ and was about $2,000 \mathrm{~kg}$ higher than the average in the evaluation area. In the fourth and further lactations, cow performance in herd $\mathrm{N}$ remained at a high level of over 11.5 thousand $\mathrm{kg}$. Whereas in the barn $\mathrm{K}$ there was a quite significant drop to 9.8 thousand $\mathrm{kg}$. Despite the decrease in cow performance in this cowshed in the fourth and further lactations, it was, however, higher than the average in Greater Poland Region by one thousand kg of milk.

The fat and protein content in milk was slightly higher in $\mathrm{K}$ barn compared to $\mathrm{N}$ barn in all lactations. It is a physiological phenomenon consisting in a negative correlation between milk yield and fat and protein content. In contrast, the yield - $\mathrm{kg}$ of fat and protein depended primarily on the amount of milk.

It can be stated that the yield for standard 305-day lactations was higher in herd N, especially in the fourth and subsequent lactations. This demonstrates the provision of favorable welfare conditions for cows. This can be explained by comparing the milking frequency in both herds. The average milking frequency in both herds was the same and was 3 times a day. However, in the barn $\mathrm{K}$ it was the same for the whole herd. But in barn $\mathrm{N}$ was variable, adapted to the current daily milk yield of each cow.

Increasing the milking frequency at a high daily output leads to an increase in the milk yield (Wolf, 2000), as well as in the amount of fat (Weiss et al., 2002). According to current views, one milking should provide 8 to $12 \mathrm{~kg}$, maximum $14 \mathrm{~kg}$ of milk (Farm Scan - Lely instructions). With greater milking, milk synthesis slows down and the well-being of cows deteriorates.

It can be stated that the yield for standard 305-day lactations was higher in herd N, especially in the fourth and subsequent lactations. This demonstrates the provision of favorable welfare conditions for cows. This can be explained by comparing the milking frequency in both herds. The average milking frequency in both herds was the same and was 3 times a day. However, in the barn $\mathrm{K}$ it was the same for the whole herd. However, in barn $\mathrm{N}$ it was variable, adapted to the current daily milk yield of each cow.

Increasing the milking frequency at a high daily output leads to an increase in milk yield (Wolf, 2000), as well as the amount of fat (Weiss, 2002). According to current views, one milking should be given 8 to $12 \mathrm{~kg}$, maximum $14 \mathrm{~kg}$ of milk (Farm Scan - Lely instructions). With greater milking, milk synthesis slows down and the well-being of cows deteriorates.

In terms of performance, for standard 305-day lactation of milk, fat, protein and dry matter in the 1st, 2nd and 3rd lactation, the differences were not statistically significant 
$(\mathrm{p} \leq 0.05)$. However, for the 4 th and further lactations, the differences were statistically significantly higher in favor of the robot milked herd $(\mathrm{p} \leq 0.05)$. In the first lactation, the percentage of fat, protein and dry matter in milk from cows in barn $\mathrm{K}$ was statistically significantly higher compared to barn N. Also, the dry matter content in milk from cows in 2 nd and 3rd lactation in barn $\mathrm{K}$ was statistically significantly higher. The authors cannot determine the reason for these differences. In other cases, the differences between the herds in fat and protein content were not statistically significant $(\mathrm{p} \leq 0.05)$.

\section{Lifetime performance and longevity}

The life yield of cows culled in both herds was different, but higher than the national average amounting to $24,121 \mathrm{~kg}$ of milk, $979 \mathrm{~kg}$ of fat and $809 \mathrm{~kg}$ of protein. Higher life efficiency of cows in barn $\mathrm{N}$ (Table 6) indicates better environmental conditions in this barn, compared to the environmental conditions in barn $\mathrm{K}$.

Table 6.

Length of use and life efficiency of cows in the herds studied

\begin{tabular}{|c|c|c|c|c|c|c|c|c|}
\hline \multirow{2}{*}{ Barn } & \multirow{2}{*}{ Year } & \multirow{2}{*}{$\begin{array}{l}\text { Number } \\
\text { of cows }\end{array}$} & \multirow{2}{*}{$\begin{array}{l}\text { Length of } \\
\text { productive } \\
\text { life (years) }\end{array}$} & \multicolumn{3}{|c|}{ Yield (kg) } & \multicolumn{2}{|c|}{ Content (\%) } \\
\hline & & & & milk & fat & protein & fat & protein \\
\hline \multirow{3}{*}{$\mathrm{K}$} & 2016 & 71 & 2.9 & 29,221 & 1,092 & 984 & 3.73 & 3.36 \\
\hline & 2017 & 87 & 2.8 & 27,029 & 1,031 & 920 & 3.81 & 3.40 \\
\hline & 2018 & 85 & 3.0 & 30,877 & 1,151 & 1,033 & 3.72 & 3.34 \\
\hline \multirow{3}{*}{$\mathrm{N}$} & 2016 & 112 & 2.8 & 30,197 & 1,143 & 1,013 & 3.78 & 3.35 \\
\hline & 2017 & 129 & 2.6 & 28,462 & 1,078 & 962 & 3.79 & 3.38 \\
\hline & 2018 & 156 & 2.9 & 31,953 & 1,220 & 1,064 & 3.82 & 3.33 \\
\hline PHF-HO & 2018 & 220,025 & 3.0 & 24,121 & 979 & 809 & 4.06 & 3.35 \\
\hline
\end{tabular}

The duration of use is a kind of an "Achilles' heel" of modern dairy cattle breeding (Wittenberg, 2000). This problem also applies to the national population for which the average useful life is 3 years, and to the herds analyzed (from 2.6 to 3 years). Too short use hinders herd reproduction and increases the milk production costs. So far, there is no good solution to this problem. The length of cows' use in both analyzed herds was similar (Table 6) and similar to the national average for the PHF-HO breed, which in 2018 was 3 years.

Milk yield is associated with the lactation phase, which explains why a shorter milking period is preferred. In herd $\mathrm{K}$, it was about a month shorter compared to the assessment of the average region of Poznan (Table 4). In herd $\mathrm{N}$ it was even more beneficial - shorter by almost 1.5 months. Thus, one can positively assess reproduction management in both herds of cows. 
Efficiency of milking cows...

\section{Cytological quality of milk}

Cytological quality of milk determined by the number of somatic cells in $1 \mathrm{ml}$ of milk (LKS) is the basic indicator of its hygienic quality. The limit value of this indicator for purchased milk is 400 thousand somatic cells in $1 \mathrm{ml}$. Milk with a higher number of somatic cells, in the range of 400 thousand up to 1 million, is considered to be derived from inflammation of the udder (subclinical inflammation), and above 1 million there is a clinical form of mastitis. In these cases, milk is disposed of. The distribution of milk samples due to LKS in subsequent years is shown in Figure 1.

In 2016, in barn K, 76.7\% of samples met the quality requirements of the purchased milk. In 2017 there was deterioration - a decrease of 3.1\%. In 2018, there was an improvement by $5.2 \%$ to the total pool of $78.8 \%$ of attempts. Higher standards of the purchased milk quality were obtained in barn N. In 2016, the advantage was 3\%, in $2017-7.8 \%$ and in $2018-3.3 \%$. In barn K, the percentage of milk samples from inflamed udders was high (Figure 1). Slightly better results were obtained in barn N. Within three years, there was some improvement. In barn $\mathrm{N}$, the percentage of milk samples indicating subclinical inflammation decreased from $9.6 \%$ in 2016 to $8.8 \%$ in 2018 . Similarly, the percentage of milk trials with clinical mastitis has decreased - from $10.7 \%$ in 2016 to $9.1 \%$ in 2018.

These results are satisfactory because it is considered desirable for the percentage of cows with clinical mastitis to be below 15\% (Sontheimer, 2011). Despite these results, however, it seems that the management of both cowsheds still has a lot to do to improve the health of cow's udders. Inflammation of an udder has a very diverse cause - they are polyetiological, and the inflammatory process occurs with a limiting factor, in accordance with Liebig's law. The literature indicates that robot milking does not automatically lead to a decrease in LKS in milk. 
S. Winnicki, W. Romaniuk, P. Mielcarek-Bocheńska, A. Borusiewicz, J. Barwicki

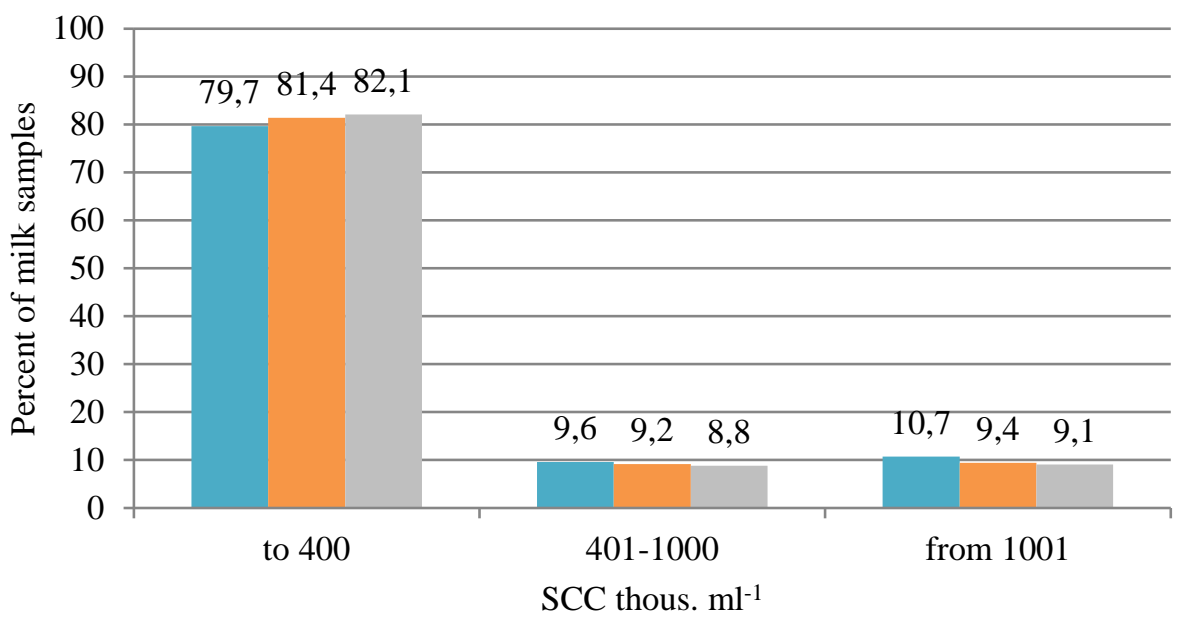

$2016 \square 2017-2018$

(a)

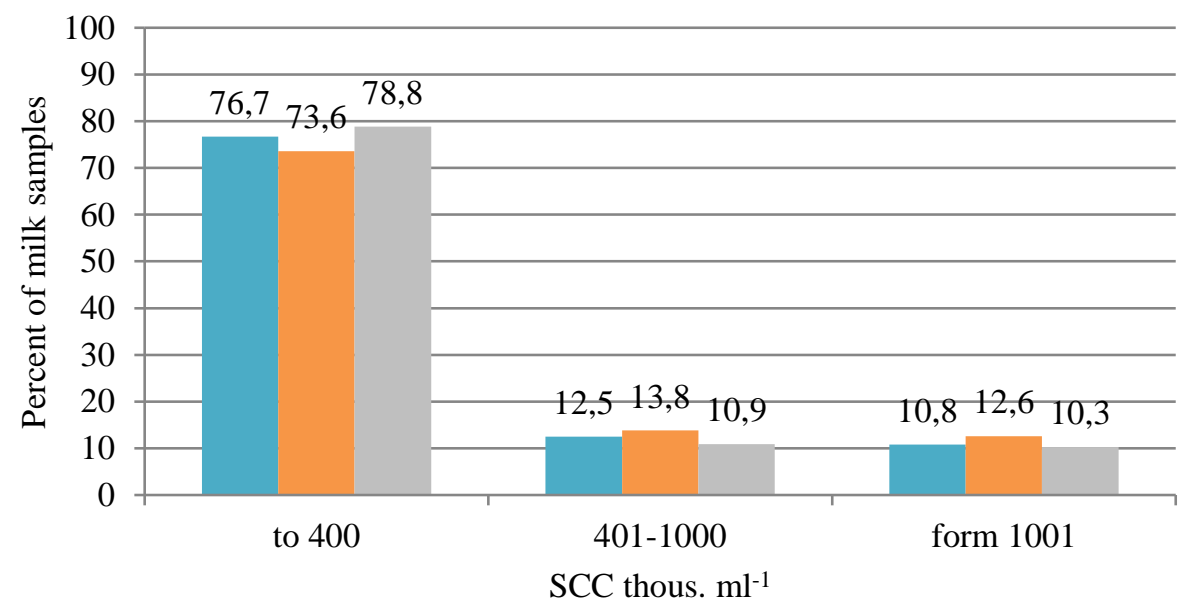

$\square 2016 \square 2017 \quad \square 2018$

(b)

Figure 1. Distribution of milk samples by number of somatic cells $(L K S)$ in subsequent years, in cowsheds (a) $N$ and (b) $K$ 
Efficiency of milking cows...

\section{Culling of cows}

The level of culling cows in barn $\mathrm{K}$ in 2017 and 2018 was almost identical and amounted to $27.9 \%$ and $27.8 \%$, respectively (Table 7 ). By contrast, in barn $\mathrm{N}$ it was a little lower - in 2017 it was $24.1 \%$, and in $2018-25.8 \%$. The distribution number of culling cows by lactation was slightly different, both in cowsheds and in years (Table 7). The median in K barn in 2017 was in the second lactation, and in other systems in the third lactation. The positive direction of changes in both cowsheds is to postpone shortages for later lactations. This is especially true for the $\mathrm{N}$ barn in 2018 , when $38.5 \%$ of cows were defective in fourth and subsequent lactations.

Table 7.

Lactation level, number and day of culling

\begin{tabular}{|c|c|c|c|c|}
\hline \multirow{3}{*}{ Culling (\%) } & \multicolumn{4}{|c|}{ Herd and year } \\
\hline & \multicolumn{2}{|c|}{$\mathrm{K}$} & \multicolumn{2}{|c|}{$\mathrm{N}$} \\
\hline & 2017 & 2018 & 2017 & 2018 \\
\hline Level & 27.9 & 27.8 & 24.1 & 25.8 \\
\hline \multicolumn{5}{|c|}{ Lactation number of culling } \\
\hline 1 & 21.8 & 16.5 & 22.5 & 19.3 \\
\hline 2 & 26.5 & 22.4 & 16.3 & 20.7 \\
\hline 3 & 23.0 & 27.0 & 27.1 & 21.5 \\
\hline 4 & 13.8 & 22.4 & 21.7 & 16.5 \\
\hline 5 & 9.2 & 4.7 & 8.5 & 16.5 \\
\hline$\geq 6$ & 5.7 & 7.0 & 3.9 & 5.5 \\
\hline Total & 100 & 100 & 100 & 100 \\
\hline \multicolumn{5}{|c|}{ Lactation day } \\
\hline to 30 & 12.6 & 11.8 & 25.5 & 18.8 \\
\hline $31-100$ & 10.3 & 12.8 & 14.0 & 17.2 \\
\hline $101-200$ & 19.5 & 11.8 & 17.1 & 13.1 \\
\hline $201-305$ & 24.1 & 31.8 & 21.7 & 24.8 \\
\hline$\geq 306$ & 33.5 & 31.8 & 21.7 & 26.3 \\
\hline Total & 100 & 100 & 100 & 100 \\
\hline
\end{tabular}

The distribution of culling depending on the lactation phase (Table 7) varies, both in years and in cowsheds. There is a similarity in one thing - a large percentage of cows are always missing in the final stage of lactation or after it, i.e. after the 201st day of lactation or after the 306th day, i.e. after the end of standard lactation. The most probable reason for the shortage during this period is not the calving of cows. Lack of reliable data on the reasons for culling of cows, does not allow to give a real answer. A large percentage of shortages occurred in the first month after calving. The probable cause of the deficiencies were postpartum complications. There were many of them, especially in barn N, which shows a bad evidence of care over cows during the peri-delivery period. 


\section{Age structure of cows}

Table 8 presents the age structure of both herds in two dates - in January 2017 and December 2018. The distribution of herds was similar in barn K in January 2017 and in barn $\mathrm{N}$ in both dates of the analysis.

Table 8.

Age structure of cow herds

\begin{tabular}{lcccccccc}
\hline & \multicolumn{3}{c}{ Number of cows in herd and date } & \multicolumn{3}{c}{ Percent of cows in herd and date } \\
\cline { 2 - 9 } Lactation & \multicolumn{3}{c}{$\mathrm{K}$} & \multicolumn{3}{c}{$\mathrm{N}$} & \multicolumn{3}{c}{$\mathrm{K}$} & \multicolumn{2}{c}{$\mathrm{N}$} \\
\cline { 2 - 9 } & $01 / 2017$ & $12 / 2018$ & $01 / 2017$ & $12 / 2018$ & $01 / 2017$ & $12 / 2018$ & $01 / 2017$ & $12 / 2018$ \\
\hline 1 & 80 & 94 & 140 & 146 & 36.4 & 42.5 & 36.3 & 36.0 \\
2 & 62 & 65 & 100 & 117 & 28.2 & 29.4 & 26.0 & 28.8 \\
3 & 43 & 34 & 82 & 68 & 19.5 & 15.4 & 21.3 & 16.7 \\
$\geq 4$ & 35 & 28 & 63 & 75 & 15.9 & 12.7 & 16.4 & 18.5 \\
\hline Total & 220 & 221 & 385 & 406 & 100 & 100 & 100 & 100 \\
\hline
\end{tabular}

The most favorable age structure was in barn $\mathrm{N}$ in December 2018. The share of young cows was $36 \%$ of the herd, and the number of the oldest cows in the fourth and subsequent lactations was $18.5 \%$. The most unfavorable age structure of cows was in barn K in December 2018. Young cows were the most $-42.5 \%$ and the least old cows $-12.7 \%$. Due to a higher proportion of older cows, it is estimated that herd management in barn $\mathrm{N}$ was better compared to herd $\mathrm{K}$.

\section{Transitory nature of selected organizational and production indicators in the examined herds}

Current requirements for milk production include maintaining an even level of milk production throughout the year. It is beneficial for both a farmer and a dairy. For a farmer, this means optimal use of the building and equipment, and facilitating the compilation of the food dose. For dairies - ensuring stable market supply. Even milk production depends on the feed base and distribution of calves. In Poland, all-year alcove maintenance dominates and is closely related to climatic conditions, in particular to the distribution and amount of precipitation. Grasslands are mainly used to produce silage. However, grazing is a margin of use. Corn silage, grass silage and alfalfa silage are standard ingredients in the feed ration. In contrast, concentrated mixtures include rapeseed meal.

The second element conditioning even milk production in the herd is the distribution of calves, which depends on reproduction management. Table 9 presents indicators that contribute to even milk production throughout the year.

In herd $\mathrm{K}$, there was a greater irregularity in daily milk production compared to herd $\mathrm{N}$ (Table 9). In barn $\mathrm{K}$ in 2016 and 2017, the difference between the maximum and minimum milk production was $24 \%$ and $22 \%$ respectively. However, in 2018 it was much higher production - by as much as $59 \%$. In barn $\mathrm{N}$, diversity of milk production was smaller and ranged from 9 to $19 \%$. From the point of view of regularity of daily milk production in barn $\mathrm{N}$, fluctuations were smaller, and therefore more favorable. 
Efficiency of milking cows...

Daily milk production from the barn depends on the current number of cows in the lactation phase and the average yield per unit. In barn $\mathrm{K}$, the difference between the minimum and maximum number of cows (Table 9) was 17\% in 2016, increased to $25 \%$ in 2017, and $37 \%$ in 2018. However, in barn N, this diversity was smaller and quite stable: in 2016 it was $14 \%$, in $2017-13 \%$ and in $2018-15 \%$. Also, the average daily milk yield from the cow was more even in barn $\mathrm{N}$ compared to barn $\mathrm{K}$. In barn $\mathrm{K}$ the difference between the lowest and the highest yield in 2016 was 10\%, and in 2017 and 2018 18\%. In barn N, however, in subsequent years $18 \%, 14 \%$ and $13 \%$ respectively. Thus, both the number of cows in the lactation phase and the average yield from the cow were more stable in barn $\mathrm{N}$ compared to barn $\mathrm{K}$.

Table 9.

Transient nature of some organizational and production indicators in the examined herds

\begin{tabular}{|c|c|c|c|c|c|c|c|}
\hline \multirow{2}{*}{ Parameter } & \multirow{2}{*}{ Year } & \multicolumn{3}{|c|}{ Values in herd $\mathrm{K}$} & \multicolumn{3}{|c|}{ Values in herd $\mathrm{N}$} \\
\hline & & $\min$. & $\max$. & difference & $\min$. & $\max$. & difference \\
\hline \multirow{3}{*}{$\begin{array}{l}\text { Daily milk production } \\
\text { by the herd (thous. } \mathrm{kg} \text { ) }\end{array}$} & 2016 & 4.6 & 5.7 & 1.1 & 9.6 & 10.5 & 0.9 \\
\hline & 2017 & 4.9 & 6.0 & 1.1 & 10.5 & 12.5 & 2.0 \\
\hline & 2018 & 4.9 & 7.8 & 2.9 & 12.0 & 13.6 & 1.6 \\
\hline \multirow{3}{*}{ Number of dairy cows } & 2016 & 161 & 188 & 27 & 288 & 327 & 39 \\
\hline & 2017 & 152 & 190 & 38 & 327 & 369 & 42 \\
\hline & 2018 & 157 & 215 & 58 & 304 & 351 & 47 \\
\hline \multirow{3}{*}{$\begin{array}{l}\text { Mean daily milk yield } \\
(\mathrm{kg})\end{array}$} & 2016 & 27.4 & 32.7 & 5.3 & 30.0 & 35.4 & 5.4 \\
\hline & 2017 & 28.4 & 33.4 & 5.0 & 32.1 & 36.7 & 4.6 \\
\hline & 2018 & 30.8 & 36.4 & 5.6 & 35.6 & 40.3 & 4.7 \\
\hline \multirow{3}{*}{$\begin{array}{l}\text { Mean lactation day } \\
\text { (days) }\end{array}$} & 2016 & 162 & 198 & 36 & 153 & 175 & 22 \\
\hline & 2017 & 151 & 186 & 35 & 151 & 174 & 23 \\
\hline & 2018 & 142 & 206 & 64 & 156 & 175 & 19 \\
\hline
\end{tabular}

Daily milk output depends on the day of lactation. With the duration of the inter-maternal period of approximately 380-400 days in the herds studied (Table 4), the length of lactation is approximately 330 days. This means that to ensure regular milk production throughout the year, the average lactation day should be around 160 - 170 days. In barn K, the average day of lactation changed significantly throughout the year. In 2016 and 2017, the differences between the extreme months were similar and amounted to 36 and 25 days. However, in 2018 it was much larger - 64 days. In barn $\mathrm{N}$ these differences were much smaller and amounted to about three weeks - from 19 to 23 days. The above data show that the management of cow reproduction in herd $\mathrm{N}$ was much better compared to herd $\mathrm{K}$.

Table 10 presents the basic performance indicators of milking robots, based on the data from November 2018 and March 2019. In both periods, the works were under loaded, as evidenced by the low number of cows -45 and 50 pieces and a too long so called "Free time" amounting to $25.6 \%$ and $31.2 \%$. The manufacturer recommends that the "free time" was 10 $15 \%$. Despite the robot being under loaded, high daily milking was obtained from $1.634 \mathrm{~kg}$ to $1.806 \mathrm{~kg}$. Calculated per year, the milking would be from 596 to 659 thousand $\mathrm{kg}$. These values are similar to those obtained in other herds with Lely robots in Poland. Similar milking was also obtained in Germany (Wittenberg, 2000). 
The herd in barn $\mathrm{N}$ was characterized by high average daily productivity - over $36 \mathrm{~kg}$ (Table 11). The average milking frequency was $2.9-3$ times a day. Therefore, the average amount of milk per milking was high and amounted to $12.2-12.6 \mathrm{~kg}$. However, milking within 8 to $12 \mathrm{~kg}$ is recommended by Lely company. The values obtained indicate the desirability of increasing the milking frequency. This has the aspect of improving cow welfare to prevent overfilling and loading of an udder. A favorable circumstance is the small number of cows per robot, which increases the milking rate. A positive element in barn $\mathrm{N}$ is the low consumption of concentrated feed for milk production. Compared to the average for herds with Lely robots, in Poland the saving was $2.6 \mathrm{~kg}$ for every $100 \mathrm{~kg}$ of milk. This was possible due to the good quality of farm feed.

Table 10.

Basic work characteristics of milking robots

\begin{tabular}{lcccc}
\hline \multirow{2}{*}{ Parameter } & Unit & \multicolumn{3}{c}{ Values obtained in the herd } \\
\cline { 3 - 5 } & & 11.2018 & 03.2019 & $\begin{array}{c}\text { Mean, according to } \\
\text { Lely data }\end{array}$ \\
\hline $\begin{array}{l}\text { Number of cows per one } \\
\text { milking parlor }\end{array}$ & cow & 45 & 50 & 55 \\
\hline $\begin{array}{l}\text { Robot "free" time } \\
\text { The amount of milk }\end{array}$ & $\%$ & 31.2 & 25.6 & 16.9 \\
$\begin{array}{l}\text { - for one milking } \\
- \text { per year }\end{array}$ & $\mathrm{kg}$ & 1,634 & 1,806 & 1,787 \\
\hline
\end{tabular}

The division of cows in a herd due to the time interval between successive milking (Table 12) shows that the most - over $60 \%$ of cows milked in the range of 6 to 12 hours. A significant part of the herd - more than $20 \%$ milked more often - up to 6 hours. The majority in this "time" group were cows that were correctly "set" to access milking. This is confirmed by proper milking - over $8 \mathrm{~kg}$. In November 2018 - 4.3\%, in March $2019-4.8 \%$ of cows were milked unnecessarily too often - with milking intervals of less than 6 hours. Less than $8 \mathrm{~kg}$ were obtained per milking. The third group consisted of rare milking cows - less than twice a day. In this group there were $5.3 \%$ to $9.6 \%$ of cows, which gave over $14 \mathrm{~kg}$ per milking. These cows should be milked more often. The results obtained indicate the existence of reserves in the form of more precise determination of the milking frequency, both increasing and decreasing the milking frequency. 
Efficiency of milking cows...

Table 11.

Basic characteristic of cow milking

\begin{tabular}{|c|c|c|c|c|}
\hline \multirow[b]{2}{*}{ Parameter } & \multirow[b]{2}{*}{ Unit } & \multicolumn{3}{|c|}{ Values obtained in the herd } \\
\hline & & 11.2018 & 03.2019 & $\begin{array}{l}\text { Mean, according to } \\
\text { Lely data }\end{array}$ \\
\hline Milking frequency per day & times & 3.0 & 2.9 & 2.9 \\
\hline \multicolumn{5}{|l|}{ The amount of milk } \\
\hline - for one milking & $\mathrm{kg}$ & 12.2 & 12.6 & 10.9 \\
\hline - for day & $\mathrm{kg}$ & 36.6 & 36.1 & 30.0 \\
\hline $\begin{array}{l}\text { The amount of concentrated } \\
\text { feed per } 100 \mathrm{~kg} \text { of milk }\end{array}$ & $\mathrm{kg}$ & 11.3 & 11.4 & 14.0 \\
\hline
\end{tabular}

Table 12.

Lower number of cows in the herd for the interval between milking and the amount of milk

\begin{tabular}{lcc}
\hline The interval between milking & \multicolumn{2}{c}{ Value obtained in the herd $(\%)$} \\
\cline { 2 - 3 } and the amount of milk & 11.2018 & 03.2019 \\
\hline Interval up to 6 hours & & \\
- milking to $8 \mathrm{~kg}$ & 4.3 & 4.8 \\
- milking over $8 \mathrm{~kg}$ & 23.9 & 17.6 \\
\hline Interval from 6 to 12 hours & 63.3 & 65.4 \\
\hline Interval over 12 hours & & \\
- milking to $14 \mathrm{~kg}$ & 3.2 & 2.6 \\
- milking over $14 \mathrm{~kg}$ & 5.3 & 100 \\
\hline Total & 100 &
\end{tabular}

\section{Other elements of the herd organization}

From the point of view of the hierarchy in the herd and the distance from the farthest stands to the milking robot, the group should not be larger than 120-130 cows (Harms and Wendl, 2009; Tischer, 2009; Schleitzer, 2009). In the analyzed barn there were two smaller groups with about 60 cows (with a single-robot) and two groups of about 120 cows (with a two stands-robot). Hence, we can assess that the organization of the herd was correct. Also, in barn $\mathrm{K}$, the herd organization was correct because the group size was 32 cows. This represented twice the number of milking stands in the milking parlor. Therefore, the cows did not have to wait long for milking in the waiting room.

\section{Conclusions}

The analysis of data from farms on which conventional $(\mathrm{K})$ and modern $(\mathrm{N})$ milk production technology was used, covering a three-year collection period, allows to state that the use of the milking robot had a positive effect on all production indicators. 
1. In barn $\mathrm{N}$ in the following years better production, health and welfare indicators for cows were achieved, but in particular:

- higher milk yields both as average annual herds and for standard 305-day of lactations and

- for the life of cows culled,

- better cytological quality of milk,

- better cow welfare due to the exclusion of chasing and waiting for milking by cows.

2. The milk production in annual periods was more even in the barn $\mathrm{N}$, equipped with milking robots.

3. There is a need for more careful control of milk yield in high yield cows in barn $\mathrm{N}$.

4. It is possible to better use milking robots by ensuring a more even distribution of calves and increasing the number of cows per milking unit of the considered robot.

\section{References}

Barańska, W., Bujalski, S., Hajdaczuk, A., Humiecki, C.M., Kiersz, Z., Michniewicz, E., Mościcki, K., Ronżewski, B., Wirkiewicz, C. (2003). Assessment of the state of dairy farms in Poland and directions of activity for the years 2003-2006. RCD Publisher, Stare Pole, Poland.

Harms, J., Wendl, G. (2009). Analysis of capacity reserves in automatic milking systems. Landtechnik, $6,432-435$.

Lehnert, S. (2012). Which milking robot for my company? In Milking robot Management, Guidebook, Top Agrar, 4, 6-13.

Schleitzer, G. (2009). Less work, higher costs. Neue Landwirtschaft, 11, 58-60.

Sontheimer, A. (2011). Secretly ill - diagnosis and treatment of Mastitis. Neue Landwirtschaft, 3, 74-76.

Szajner, P. (2017). Milk production, in The milk market - the state and prospects, P. Szajner (eds.), IERiGŻ - PiB, Warsaw, Poland, 7-13.

Tischer, M. (2009). Robots remain in demand. Neue Landwirtschaft, 12, 86.

Weiss, M., Hilger, M., Meyer, H.H.D., Bruckmaier, R.M. (2002) Varied milking intervals and their influence on milk composition. Milkscience International, 57, 246-249.

Winnicki, S., Jugowar, L.J. (2018). Modern solutions in barn - in practice, in Problems of animal production intensification with regard to environment protection, EU standards and alternative energy production, W. Romaniuk (eds.), ITP Falenty, Poland, 227-237.

Wittenberg, K. (2000). Make sharp milk types more problems? Top agrar, 1, 8-10.

Wolf, J. (2000). Keeping cows taking into account high milk yields. Archiv fur Tierzucht, 43, 51-57. 


\section{WYDAJNOŚĆ DOJU KRÓW ZA POMOCĄ ROBOTA W DUŻYM STADZIE}

Streszczenie. Celem pracy były badania dotyczące wykorzystania robotów udojowych w porównaniu do stosowania hal udojowych w oborach gospodarstw rodzinnych. Prezentowane badania oprócz wiedzy naukowej dają również praktyczne zastosowanie nowych technologii jako dobrej praktyki rolniczej w gospodarstwie. Testy przeprowadzono jednocześnie w dwóch oborach należących do tego samego gospodarstwa. W oborze $\mathrm{K}$ dojenie odbywało się przy wykorzystaniu hali udojowej rybia ość, a w oborze N stosowano roboty udojowe. Przedstawiono wyniki obejmujące trzy lata badań od roku 2016 do 2018 roku. Stwierdzono, że wydajność mleczna w pierwszej laktacji krów w obu oborach była prawie identyczna, podczas gdy w drugiej i kolejnych laktacjach krowy w oborze $\mathrm{N}$ miały większą wydajność. W oborze $\mathrm{N}$ uzyskano około $3 \%$ więcej mleka z LKS poniżej 400 tys. $\mathrm{ml}^{-1}$, w porównaniu do obory K. Czas wykorzystania krów w obu oborach był podobny, natomiast w oborze $\mathrm{N}$ całkowita wydajność życiowa krów była wyższa o około $1000 \mathrm{~kg}$ mleka. W oborze $\mathrm{N}$ jednorodność produkcji mleka przez cały rok była bardziej wyrównana niż w stodole K. Wykorzystanie robota udojowego wiązało się z pewnymi rezerwami ze względu na małą liczbę krów na stanowisko dojenia i potrzebę lepszego dostosowania czasów doju do aktualnej wydajności krów. Robot udojowy poprawia dobrostan krów i zapewnia wysoką wydajność mleka oraz dobrą jakość cytologiczną mleka.

Słowa kluczowe: krowa; robot udojowy; hala udojowa, mleko; jakość mleka; jednolitość produkcji 